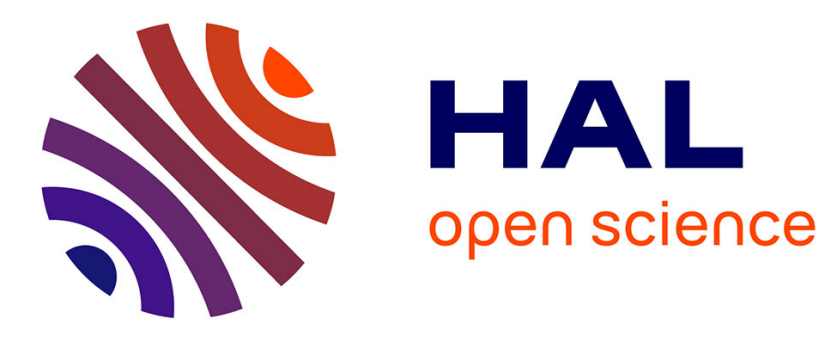

\title{
Io's dry body shaped by atmospheric instability
}

Olivier Mousis, Emmanuel Marcq, Artyom Aguichine, François Leblanc, Kathleen Mandt, Antoine Schneeberger, Martin Turbet

\section{To cite this version:}

Olivier Mousis, Emmanuel Marcq, Artyom Aguichine, François Leblanc, Kathleen Mandt, et al.. Io's dry body shaped by atmospheric instability. European Planetary Science Congress. EPSC 2021, Sep 2021, Virtual Meeting, France. pp.306-322, 10.5194/epsc2021-187 . insu-03313836

\section{HAL Id: insu-03313836 \\ https://hal-insu.archives-ouvertes.fr/insu-03313836}

Submitted on 4 Aug 2021

HAL is a multi-disciplinary open access archive for the deposit and dissemination of scientific research documents, whether they are published or not. The documents may come from teaching and research institutions in France or abroad, or from public or private research centers.
L'archive ouverte pluridisciplinaire HAL, est destinée au dépôt et à la diffusion de documents scientifiques de niveau recherche, publiés ou non, émanant des établissements d'enseignement et de recherche français ou étrangers, des laboratoires publics ou privés.

\section{(c)(1)}

Distributed under a Creative Commons Attribution| 4.0 International License 
EPSC Abstracts

Vol. 15, EPSC2021-187, 2021, updated on 01 Aug 2021

https://doi.org/10.5194/epsc2021-187

European Planetary Science Congress 2021

(C) Author(s) 2021. This work is distributed under

the Creative Commons Attribution 4.0 License.

\section{Io's dry body shaped by atmospheric instability}

Olivier Mousis ${ }^{1}$, Emmanuel Marcq ${ }^{2}$, Artyom Aguichine ${ }^{1}$, François Leblanc ${ }^{2}$, Kathleen Mandt ${ }^{3}$, Antoine Schneeberger ${ }^{1}$, and Martin Turbet ${ }^{4}$

${ }^{1}$ Aix Marseille Univ, CNRS, CNES, LAM, Marseille, France

${ }^{2}$ LATMOS/IPSL, UVSQ, Université Paris-Saclay, Sorbonne Université, CNRS, Guyancourt, France

${ }^{3}$ Johns Hopkins University Applied Physics Laboratory, 240-592-0262, Laurel, MD, USA

${ }^{4}$ Observatoire astronomique de l'Université de Genève, 51 chemin des Maillettes, Switzerland

One of the outstanding questions regarding the architecture of the Galilean moons system is the nature of the processes that shaped its density gradient, which results from the fact that Ganymede and Callisto share an ice-to-rock ratio close to unity while Io and Europa are heavily depleted in volatiles. Two categories of scenarios, gathered in two distinct phases of moons formation and evolution, have been proposed to account for this density gradient in the literature: either the building blocks of the two innermost moons Io and Europa have been depleted in volatiles during their migration in the hot part of the Jovian circumplanetary disk [1-3], or they initially accreted icerich building blocks in a colder environment. In this case, their primitive oceans would have mostly vanished via hydrodynamic escape due to the high accretional energy [4]. 


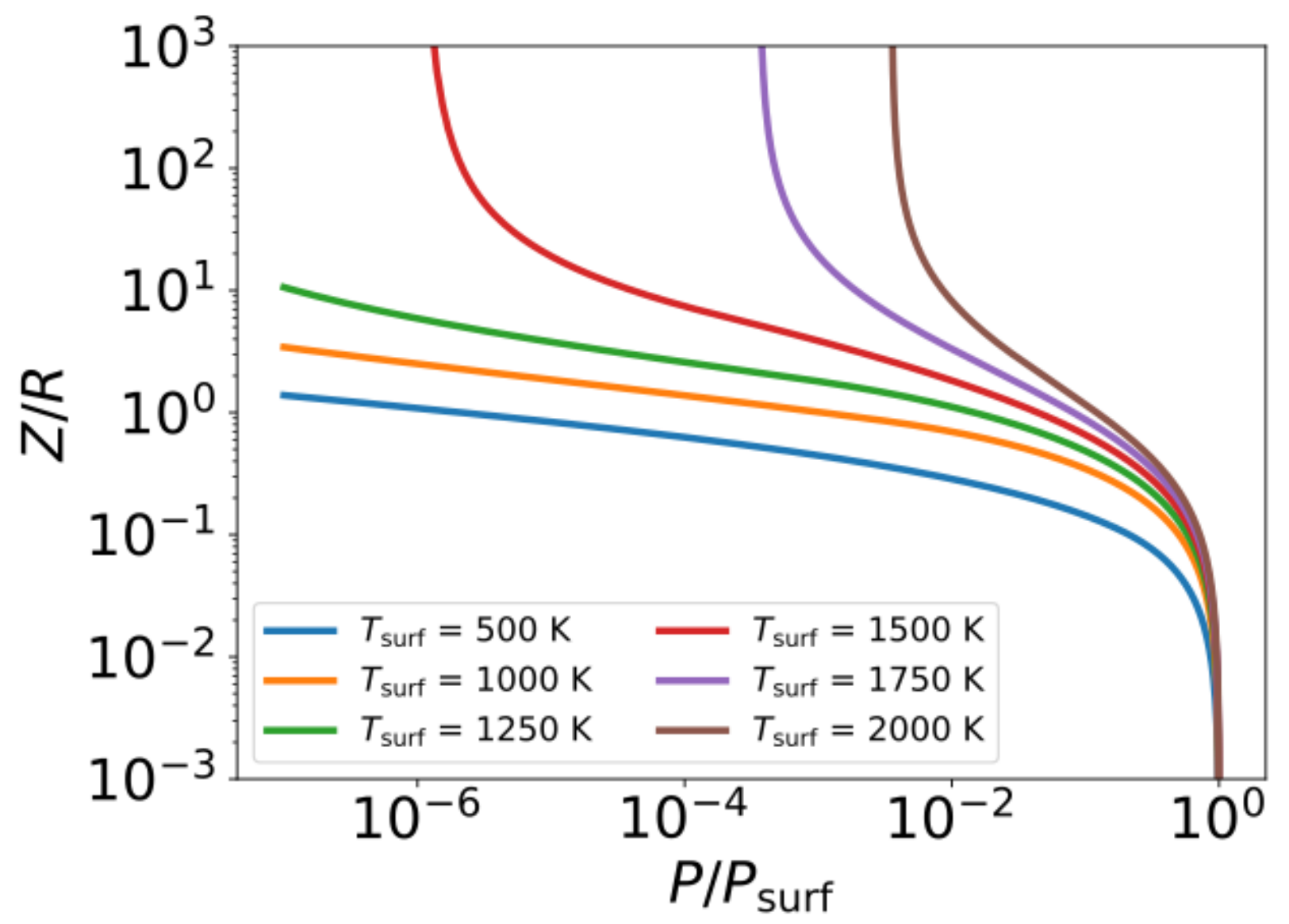

Figure 1.Thickness of Io's primitive atmosphere (in units of satellite radius) expressed as a function of pressure (in units of surface pressure) for several temperatures.

Here, we investigate the possibility that Io also accreted from water-rich building blocks and that its hydrosphere vanished because of hydrostatic instability, i.e. when the gravity at a given height is insufficient to retain gas. Io's putative primordial atmosphere would be either situated atop of a magma mantle, or a coexisting liquid ocean, depending on the surface temperature and pressure. To do so, we use the atmosphere model elaborated by $[5,6]$ in which the properties of a $1 D$ spherical atmosphere of water are generated by integrating the thermodynamic profiles bottom to top. The model takes as inputs the satellite's mass and radius, as well as the thermodynamic conditions at its bottom. Figure 1 represents the atmosphere thickness as a function of surface pressure and temperature. It shows that atmospheric thicknesses higher than 10 Io's radii are reached for surface temperatures equal or higher than $1250 \mathrm{~K}$, indicating that such $\mathrm{H}_{2} \mathrm{O}$-dominated atmospheres would be gravitationally unstable at those temperatures. Such high temperatures needed at the base of the atmosphere to favor hydrostatic instabilitycould result from the combination of accretional heating and heating generated by greenhouse effect. If effective, this mechanism would naturally explain why Io is devoid in volatiles without the need of invoking pre-accretional formation scenarios.

[1] Canup, R.M. \& Ward, W.R. 2002, AJ, 124, 3404. doi:10.1086/344684

[2] Mousis, O. \& Gautier, D. 2004, PSS, 52, 361. doi:10.1016/j.pss.2003.06.004

[3] Ronnet, T., Mousis, O., \& Vernazza, P. 2017, ApJ, 845, 92. doi:10.3847/1538-4357/aa80e6

[4] Bierson, C.J. \& Nimmo, F. 2020, ApJL, 897, L43. doi:10.3847/2041-8213/aba11a 
[5] Marcq, E., Salvador, A., Massol, H., et al. 2017, JGR (Planets), 122, 1539. doi: $10.1002 / 2016$ JE005224

[6] Marcq, E. 2012, JGR (Planets), 117, E01001. doi:10.1029/2011JE003912 